\title{
Shikimic Acid and Salicylic Acid Induced Protection on Growth Vigor, Seed Yield and Biochemical Aspects of Yielded Seeds of Vicia faba Plants Infected by Botrytis fabae
}

Heshmat Soliman Aldesuquy*

Botany Department, Faculty of Science, Mansoura University, Egypt

\begin{abstract}
The present work was conducted to evaluate the protective effect of seed presoaking in shikimic acid $(0.4 \mathrm{mM})$, salicylic acid $(0.7 \mathrm{mM})$ or their combination on faba bean plants (Vicia faba L.) variety Giza 429 as alternatives to fungicide Ridomil $M Z$ to increase faba bean resistance against chocolate spot disease. Concerning the growth, the obtained results showed that infection with $B$. fabae caused noticeable reduction in root and shoot growth vigor (fresh \& dry biomasses, length, density, distribution, shoot diameter, R/S ratio, leaf area and number of nodes). On the other hand, exogenous application of shikimic acid, salicylic acid or their interactiom could counteract the adverse effects of $B$. fabae by improvement growth vigor of root and shoot as well as leaf area. Chocolate spot disease caused marked decreases in all yield components of faba bean plants, total carbohydrates, total nitrogen, total protein and nucleic acid (DNA and RNA) contents of yielded seeds. On the other hand, seed presoaking in phenolic compounds improve the yield components and its biochemical aspects more than the fungicide. It appeared that seed yield was positively correlated with all growth parameters as well as yield attributes and biochemical aspects of yielded seeds of faba bean plants.
\end{abstract}

Keywords: Botrytis fabae; Salicylic acid; Shikimic acid; Growth vigor; Yield

\section{Introduction}

Chocolate spot disease caused by B. fabae is a wide spread disease, occurring in many regions of the world where broad bean is grown [1], causing losses ranging from minor to complete failure of crop. Losses depend on the severity of infection, the time at which infection occurred and the amount of rainfall. In unprotected crops, the disease can be expected to reduce yields by at least $30-50 \%$ in a bad year.

There are many seed-borne fungi, while a number of fungi are serious pathogens on flowers and maturing seeds. These pathogens reduce the yield of seed both quantitatively and qualitatively. Other fungi, including saprophytes and very weak parasites may lower the quality of seeds. The most common seed borne fungi listed on faba bean are: Ascochyta fabae, which causes leaf and pod spot; Botrytis cinerea, the cause of grey mould; $B$. fabae, the cause of chocolate spot; Fusarium sp., the cause of foot rot and wilt; and Rhizoctonia solani, the cause of damping-off of seedlings [2].

Because of hazards of pesticides in general, and fungicides in specific, on public health and environmental balance, a relatively recent direction of pest control management was introduced. The so called "induced resistance" is a promising modern approach with a broad spectrum in plant disease control. It could be induced in plants by applying chemical elicitors [3]. Chemical elicitors (inducers) have been used to predispose the defense mechanisms in plants against diseases. In addition [4] reported that chemical inducers stimulate the inherent defense mechanisms of the host plant. Such chemical inducers are assumed to be much more environmentally sound than synthetic fungicides, to have a lower economic cost for farmers, to lack environmental and toxicological risks, and to create induced systematic resistance in the hosts against several pathogens.

Phenolic compounds play an important role in plant growth as internal physiological regulators or chemical messengers within the intact plant [5]. Shikimic acid stimulates growth parameters, leaf area, transpiration rate, photosynthetic pigments, total soluble sugars and sucrose, yield capacity and $\mathrm{C}^{14}$ fixation in cowpea [6].

Salicylic acid plays an important role in controlling plant growth and development, pigment content, photosynthesis and transpiration rates, ion uptake and transport, seed germination, fruit yield, glycolysis, flowering in thermo genic plant and induces changes in leaf anatomy and chloroplast ultrastructure [7,8]. Elkhodary [9] observed a significant increase in growth characteristics, pigment contents, photosynthetic rate and carbohydrate content in maize, sprayed with salicylic acid. In cucumber and tomato, the fruit yield enhanced significantly when the plants were sprayed with lower concentrations of salicylic acid [10].

In previous work, the infection of Vicia faba by $B$. fabae caused a massive depletion in pigments content and chloroplasts number while application of phenolic compounds caused an obvious increase in these parameters. The ultrastructure changes of chloroplasts were obvious on the disorganization of membrane system, thickening of envelope and absence of starch grains. Application of the phenolic compounds improved plants by increasing pigments content, chloroplasts number and their ultrastructure [11]. Thus, the present work was undertaken to evaluate the roles displayed by shikimic and salicylic acids as chemical elicitors compared with Ridomil MZ as a fungicide on protection of growth vigor, yield and yield attributes as well as the biochemical

*Corresponding author: Aldesuquy Heshmat Soliman, Botany Department Faculty of Science, Mansoura University, Egypt, P.O Box 35516, Tel +201006573700; E-mail: heshmat-aldesuquy@hotmail.com

Received September 11, 2015; Accepted September 24, 2015; Published September 28, 2015

Citation: Soliman AH (2015) Shikimic Acid and Salicylic Acid Induced Protection on Growth Vigor, Seed Yield and Biochemical Aspects of Yielded Seeds of Vicia faba Plants Infected by Botrytis fabae. J Plant Pathol Microb 6: 304. doi:10.4172/2157 7471.1000304

Copyright: @ 2015 Soliman AH. This is an open-access article distributed under the terms of the Creative Commons Attribution License, which permits unrestricted use, distribution, and reproduction in any medium, provided the original author and source are credited. 
aspects of yielded seeds faba bean in response to infection by Botrytis fabae.

\section{Materials and Methods}

\section{Planting and growth conditions}

Seeds of faba bean (Vicia fabae L.) susceptible $\left[\mathrm{G}_{429}\right]$ were surface sterilized in $0.01 \%$ mercuric chloride for $3 \mathrm{~min}$, subsequently rinsed with sterilized water several times. Sterilized seeds were divided into 4 sets. Seeds of the 1st, 2nd,3rd and 4th set were soaked in distilled water, $0.4 \mathrm{mM}$ shikimic acid (SH), $0.7 \mathrm{mM}$ salicylic acid (SA) and shikimic acid+salicylic acid (SH+SA), respectively, for $12 \mathrm{hr}$. On 14 November 2008 , seeds of each set were planted in plastic pots ( 5 seeds per pot) filled with $12-13 \mathrm{~kg}$ mixed soil (clay and sand 2:1, v/v). All plants were watered regularly to near field capacity with tap water. Plants were maintained under natural conditions (day temperature $22^{\circ} \mathrm{C}$, night temperature $18^{\circ} \mathrm{C}$ and $16 \mathrm{hr}$ photo-period)

Forty five days later from planting, faba bean plants were inoculated with a spore suspension $\left(40 \times 10^{4}\right.$ spores $\left./ \mathrm{ml}\right)$ of $B$. fabae. Untreated plants (control) were sprayed with sterilized water at the same time. Chemical fungicide Ridomil MZ at the rate of $(250 \mathrm{~g} / 100 \mathrm{~L})$ was applied as spray treatments four times at 15-day intervals.

The experimental design can be summarized as follows:

- Uninoculated treatment (control) (Cont)

- B. fabae treatment (pathogen) (P)

- Shikimic acid treatment (SH)

- Shikimic acid+B. fabae treatment $(\mathrm{SH}+\mathrm{P})$

- Salicylic acid treatment (SA)

- Salicylic acid+B. fabae treatment (SA+P)

- Salicylic acid+Shikimic acid treatment (SA+SH)

- Salicylic acid+Shikimic acid+B. fabae treatment $(\mathrm{SA}+\mathrm{SH}+\mathrm{P})$

- Fungicide (Ridomil MZ) (F)

- Fungicide+B. fabae treatment $(\mathrm{F}+\mathrm{P})$

Fifteen plants from each treatment were harvested after 70 days from planting for estimation of growth parameters and at harvest (i.e.140 days from planting) for estimation of yield and yield components, while triplicates were used for analyses of biochemical aspects of yielded seeds.

Leaf area was measured by weighing the image of the $3^{\text {rd }}$ compound leaf and comparing that mass with the mass of a known area.

\section{Analysis of yield as follow}

Shoot or root distribution=Fresh mass / Length [12]

Shoot or root density=Dry mass / Length [12]

Harvest index $=\frac{\text { seed weight }(\mathrm{g}) / \text { plant }}{\text { straw weight }(\mathrm{g}) / \text { plant }} \times 100[13]$

Mobilization index $=\frac{\text { crop weight }(\mathrm{g}) / \text { plant }}{\text { straw weight }(\mathrm{g}) / \text { plant }}[13]$

Crop index $=\frac{\text { seed weight }(\mathrm{g}) / \text { plant }}{\text { seed weight }(\mathrm{g}) / \text { plant }+ \text { straw weight }(\mathrm{g}) / \text { plant }}$

$$
\text { Relative seed yield }=\frac{\text { yield in treatment }}{\text { yield in control }} \times 100[13]
$$

\section{Estimation of carbohydrates}

Sugars were extracted by overnight submersion of dry tissue of the yielded seeds in $80 \%(\mathrm{v} / \mathrm{v})$ ethanol at $25^{\circ} \mathrm{C}$ with periodic shaking.

\section{Estimation of glucose}

Glucose content was estimated using O-toluidine procedure of Feteris [14]. One $\mathrm{ml}$ aliquot of the alcoholic extract was heated with $5 \mathrm{ml} \mathrm{O}$-toluidine reagent $(60 \mathrm{ml} \mathrm{O}$-toluidine and $2 \mathrm{~g}$ thiourea made up to $100 \mathrm{ml}$ with glacial acetic acid) and incubated for 15 minutes at $97^{\circ} \mathrm{C}$. Optical density of the developed color was measured at $625 \mathrm{~nm}$ using spectrophotometer. Glucose content was calculated by the use of a calibration curve obtained using standard pure glucose solutions.

\section{Estimation of sucrose}

Sucrose was determined using the modification of Handel [15]. Three $\mathrm{ml}$ of freshly prepared anthrone reagent (150 mg anthrone+100 of $72 \% \mathrm{H}_{2} \mathrm{SO}_{4}$ ) was then added to the cooled reaction product, and the mixture was heated at $97^{\circ} \mathrm{C}$ for 5 minutes, cooled, and the developed color was read at $620 \mathrm{~nm}$. The amounts of sucrose in plant extract were determined from calibration curve of standard pure sucrose solutions.

\section{Estimation of total soluble sugars}

Total soluble sugars were analyzed according to the modification of Yemm and Willis [16] and reading the cooled samples at $625 \mathrm{~nm}$ using spectrophotometer.

\section{Estimation of polysaccharides}

To remove sugars, the plant tissue is treated with $80 \%$ ethanol then starch is extracted with perchloric acid. In hot acidic reaction, starch is hydrolysed into glucose and dehydrated to hydroxymethyl furfural. This compound forms a green colored product with anthrone reagent. The method used for estimation of polysaccharides was that of Thayermanavan and Sadasivam [17].

\section{Estimation of total-N}

The total nitrogen was determined by the conventional semimicromodification of Kjeldahl method of Chinbal et al. [18].

\section{Estimation of nucleic acids}

DNA and RNA contents were estimated according to the method of Sadasivam and Manickam [19].

\section{Estimation of protein}

Protein content was determined according to the method adopted by Bradford [20].

\section{Estimation of total phenols}

Total phenols estimation was carried out with folin ciocalteau reagent according to the method described by Malik and Singh [21].

\section{Statistical analysis}

Using SPSS program, a test for significant differences between means at $\mathrm{P} \leq 0.05$ was performed using LSD test [22]. Furthermore, standard error was calculated to test the differences among mean values. 
Citation: Soliman AH (2015) Shikimic Acid and Salicylic Acid Induced Protection on Growth Vigor, Seed Yield and Biochemical Aspects of Yielded Seeds of Vicia faba Plants Infected by Botrytis fabae. J Plant Pathol Microb 6: 304. doi:10.4172/2157-7471.1000304

\section{Results}

\section{Changes in growth vigor of root}

As compared to control values, the results in Table 1 showed that, pathogen decreased $(\mathrm{P} \leq 0.05)$ root biomasses (fresh and dry masses), root length, root density, root distribution and root/shoot ratio. Also, fungicide caused an obvious decrease in all parameters except root distribution in the presence or absence of pathogen. Application of shikimic acid, salicylic acid or their combination caused significant increase $(P \leq 0.05)$ in root biomasses, length and density, while salicylic or shikimic acid alone caused additional increase $(\mathrm{P} \leq 0.05)$ in root/ shoot ratio. As compared to untreated infected plants, application of shikimic acid and shikimic + salicylic acid showed significant increase $(\mathrm{P} \leq 0.05)$ in all growth criteria of root. The magnitude of increase was more pronounced with salicylic acid alone.

\section{Changes in growth vigor of shoot}

The changes in growth vigor of shoot of the differently treated faba bean plants were presented in Table 2. The data showed that pathogen as well as fungicide+pathogen caused noticeable decreases $(\mathrm{P} \leq 0.05)$ in growth vigor of shoot of faba bean plants (i.e., shoot fresh and dry masses, shoot length, shoot diameter, shoot density, shoot distribution, leaf area and number of nodes). Moreover, fungicide caused significant decrease in shoot biomasses (fresh and dry), length, diameter and density as well as leaf area in controlled plants in comparing with control values. On the other hand, seed presoaking in shikimic acid, salicylic acid or their combination caused significant increase $(\mathrm{P} \leq 0.05)$ in these parameters of controlled plant. As compared with untreated infected faba bean plants, application of phenolic compounds to infected plants alleviated the effect of pathogen on growth vigor of shoot. Furthermore, the magnitude of response was more pronounced with salicylic acid treatment.

\section{Changes in yield and yield components}

In relation to control values, pathogen either alone or with shikimic acid, salicylic acid or their combination on yield components of faba bean under infection with $B$. fabae, presence of fungicide caused drastic reduction $(\mathrm{P} \leq 0.05)$ in all yield components of faba bean plants. Furthermore, fungicide alone caused an obvious decrease in straw yield per plant, relative seed yield and biological yield as compared to control plants. On the other hand, seed presoaking in shikimic or salicylic acids and their combination induced massive increase $(\mathrm{P} \leq 0.05)$ in nearly all yield components of faba bean plants (Tables 3 and 4 ). In

\begin{tabular}{|c|c|c|c|c|c|c|}
\hline \multirow{2}{*}{ Parameters } & \multicolumn{6}{|c|}{ Growth vigor of root } \\
\hline & $\begin{array}{l}\text { Fresh biomass } \\
\text { (g) }\end{array}$ & $\begin{array}{l}\text { Dry biomass } \\
\text { (g) }\end{array}$ & $\begin{array}{l}\text { Length } \\
\text { (cm) }\end{array}$ & $\begin{array}{l}\text { Density } \\
\left(\mathrm{g} \mathrm{cm}^{-1}\right)\end{array}$ & $\begin{array}{l}\text { Distribution } \\
\quad\left(\mathrm{g} \mathrm{cm}^{-1}\right)\end{array}$ & $\begin{array}{c}\text { Root/ } \\
\text { shoot } \\
\text { ratio }\end{array}$ \\
\hline Cont & $7.04 \pm 0.287$ & $0.97 \pm 0.137$ & $15.47 \pm 0.112$ & $0.062 \pm 0.001$ & $0.455 \pm 0.018$ & $0.225 \pm 0.001$ \\
\hline $\mathbf{P}$ & $3.31 \pm 0.173$ & $0.52 \pm 0.094$ & $9.35 \pm 0.160$ & $0.055 \pm 0.007$ & $0.354 \pm 0.013$ & $0.168 \pm 0.002$ \\
\hline $\mathbf{F}$ & $6.61 \pm 0.068$ & $0.87 \pm 0.172$ & $14.42 \pm 1.18$ & $0.060 \pm 0.002$ & $0.458 \pm 0.050$ & $0.217 \pm 0.017$ \\
\hline$F+P$ & $4.68 \pm 0.204$ & $0.61 \pm 0.127$ & $10.43 \pm 3.90$ & $0.058 \pm 0.003$ & $0.449 \pm 0.068$ & $0.169 \pm 0.004$ \\
\hline SH & $8.22 \pm 0.184$ & $1.19 \pm 0.112$ & $17.52 \pm 0.157$ & $0.068 \pm 0.011$ & $0.469 \pm 0.025$ & $0.235 \pm 0.002$ \\
\hline $\mathrm{SH}+\mathrm{P}$ & $6.73 \pm 0.134$ & $0.97 \pm 0.088$ & $14.50 \pm 0.468$ & $0.067 \pm 0.007$ & $0.464 \pm 0.011$ & $0.212 \pm 0.025$ \\
\hline SA & $9.23 \pm 0.238$ & $1.32 \pm 0.143$ & $18.83 \pm 1.15$ & $0.070 \pm 0.005$ & $0.490 \pm 0.029$ & $0.248 \pm 0.006$ \\
\hline$S A+P$ & $7.49 \pm 0.305$ & $1.04 \pm 0.125$ & $15.38 \pm 0.11$ & $0.068 \pm 0.002$ & $0.487 \pm 0.011$ & $0.218 \pm 0.005$ \\
\hline $\mathrm{SH}+\mathrm{SA}$ & $7.79 \pm 0.074$ & $1.10 \pm 0.203$ & $15.9 \pm 0.187$ & $0.069 \pm 0.009$ & $0.490 \pm 0.003$ & $0.224 \pm 0.003$ \\
\hline $\mathrm{SH}+\mathrm{SA}+\mathrm{P}$ & $6.79 \pm 0.152$ & $0.96 \pm 0.091$ & $14.51 \pm 0.285$ & $0.066 \pm 0.009$ & $0.468 \pm 0.009$ & $0.212 \pm 0.005$ \\
\hline LSD at $P \leq 0.05$ & 0.24 & 0.026 & 0.31 & 0.002 & 0.017 & 0.005 \\
\hline
\end{tabular}

Table 1: Effect of shikimic acid, salicylic acid and their combination on growth vigor of root of faba bean plants infected with chocolate spot disease. Data are represented as means \pm standard errors from 10 replicates.

\begin{tabular}{|c|c|c|c|c|c|c|c|c|}
\hline Parameters & \multicolumn{8}{|c|}{ Growth vigor of shoot } \\
\hline & Fresh mass (g) & Dry mass $(\mathbf{g})$ & Length $(\mathrm{cm})$ & Diameter $(\mathrm{mm})$ & $\begin{array}{l}\text { Density } \\
\left(\mathrm{g} \mathrm{cm}^{-1}\right)\end{array}$ & $\begin{array}{c}\text { Distribution } \\
\left(\mathrm{g} \mathrm{cm}^{-1}\right)\end{array}$ & $\begin{array}{l}\text { Leaf area } \\
\quad\left(\mathrm{cm}^{2}\right)\end{array}$ & No. of nodes \\
\hline Cont & $47.51 \pm 0.567$ & $6.45 \pm 0.068$ & $68.73 \pm 0.432$ & $6.01 \pm 0.217$ & $0.093 \pm 0.001$ & $0.691 \pm 0.007$ & $40.95 \pm 0.634$ & $19.00 \pm 0.354$ \\
\hline $\mathbf{P}$ & $29.40 \pm 0.306$ & $3.58 \pm 0.140$ & $55.47 \pm 0.447$ & $4.60 \pm 0.189$ & $0.064 \pm 0.003$ & $0.529 \pm 0.005$ & $27.68 \pm 0.146$ & $15.00 \pm 0.274$ \\
\hline $\mathbf{F}$ & $45.16 \pm 0.305$ & $5.83 \pm 0.112$ & $66.27 \pm 0.130$ & $5.50 \pm 0.379$ & $0.088 \pm 0.002$ & $0.681 \pm 0.005$ & $38.56 \pm 0.506$ & $18.62 \pm 0.354$ \\
\hline$F+P$ & $39.85 \pm 0.235$ & $4.49 \pm 0.152$ & $61.38 \pm 0.580$ & $5.32 \pm 0.213$ & $0.073 \pm 0.003$ & $0.649 \pm 0.004$ & $33.92 \pm 0.572$ & $17.75 \pm 0.500$ \\
\hline SH & $55.47 \pm 0.580$ & $7.54 \pm 0.158$ & $74.39 \pm 0.449$ & $6.58 \pm 0.209$ & $0.101 \pm 0.002$ & $0.745 \pm 0.009$ & $43.19 \pm 0.274$ & $21.12 \pm 0.354$ \\
\hline $\mathrm{SH}+\mathrm{P}$ & $50.53 \pm 0.715$ & $6.19 \pm 0.307$ & $68.34 \pm 0.514$ & $6.11 \pm 0.100$ & $0.090 \pm 0.005$ & $0.739 \pm 0.013$ & $40.90 \pm 0.232$ & $19.12 \pm 0.500$ \\
\hline SA & $58.17 \pm 0.561$ & $8.26 \pm 0.119$ & $75.79 \pm 0.592$ & $7.03 \pm 0.098$ & $0.109 \pm 0.002$ & $0.767 \pm 0.009$ & $44.39 \pm 0.321$ & $21.87 \pm 0.500$ \\
\hline SA+P & $53.54 \pm 0.447$ & $7.09 \pm 0.195$ & $70.37 \pm 0.112$ & $6.13 \pm 0.153$ & $0.100 \pm 0.003$ & $0.761 \pm 0.007$ & $41.63 \pm 0.582$ & $20.75 \pm 0.418$ \\
\hline $\mathrm{SH}+\mathrm{SA}$ & $56.00 \pm 0.403$ & $7.32 \pm 0.091$ & $70.75 \pm 0.187$ & $6.82 \pm 0.125$ & $0.103 \pm 0.009$ & $0.791 \pm 0.003$ & $42.57 \pm 0.442$ & $21.00 \pm 0.548$ \\
\hline $\mathrm{SH}+\mathrm{SA}+\mathrm{P}$ & $51.75 \pm 0.025$ & $6.71 \pm 0.142$ & $68.38 \pm 0.285$ & $6.15 \pm 0.074$ & $0.098 \pm 0.010$ & $0.756 \pm 0.004$ & $41.49 \pm 0.514$ & $20.63 \pm 0.274$ \\
\hline LSD at $P \leq 0.05$ & 0.99 & 0.32 & 0.31 & 0.33 & 0.004 & 0.015 & 1.48 & 1.27 \\
\hline
\end{tabular}

Table 2: Effect of shikimic acid, salicylic acid and their combination on growth vigor of shoot of faba bean plant infected with chocolate spot disease. Data are represented as means \pm standard errors from 10 replicates. 
Citation: Soliman AH (2015) Shikimic Acid and Salicylic Acid Induced Protection on Growth Vigor, Seed Yield and Biochemical Aspects of Yielded Seeds of Vicia faba Plants Infected by Botrytis fabae. J Plant Pathol Microb 6: 304. doi:10.4172/2157-7471.1000304

majority of cases, these applied phenolics caused additional increases in yield components of infected faba bean plants when compared with untreated infected plants. In general, the treatment of salicylic acid had the most pronounced effect (Tables 3 and 4 ).

Changes in biochemical aspects of yielded seeds

\section{Changes in carbohydrates content}

Data in Table 5 cleared that, infection with $B$. fabae resulted in marked decrease $(\mathrm{P} \leq 0.05)$ in all carbohydrate fractions (glucose, sucrose, total soluble sugars, polysaccharides and total carbohydrates). Also, this effect was observed in case of infected plant sprayed with fungicide. On contrast, application of shikimic acid or salicylic acid induced significant increase $(\mathrm{P} \leq 0.05)$ in carbohydrates content of the yielded faba bean seeds. Their combination had insignificant effect on glucose and total soluble sugars as compared to control values. In relation to carbohydrates fraction contents in untreated infected plant, seed pretreatment with shikimic acid, salicylic acid or their combination led to additive significant increases in almost all of these carbohydrate fractions. In comparison to all treatments, the effect of salicylic acid was the most effective one.

\section{Changes in total phenols, total nitrogen, total protein and nucleic acids (DNA \& RNA) content}

As compared to control values, data in Table 6 showed that total phenols content in yielded faba bean seeds were accumulated in response to infection. In general, application of phenolic compounds; shikimic acid, salicylic acid or their combination, led to progressive increases in the total phenols content in controlled and infected plants. Pathogen resulted in massive decrease in total nitrogen, total protein and nucleic acids (DNA\& RNA) contents in the yielded faba bean seeds. Moreover, fungicide alone caused marked reduction $(\mathrm{P} \leq 0.05)$ in total nitrogen and insignificant effect on total protein and nucleic acids contents. In addition, seed presoaking in shikimic acid or salicylic acid induced significant increase $(\mathrm{P} \leq 0.05)$ in total nitrogen, total protein and nucleic acids contents.

As compared to untreated infected plants, seed priming with phenolic compounds resulted in complete alleviation of the adverse effect of B. fabae infection. As compared to all treatments, salicylic acid appeared to be the most obvious treatment in inducing the tolerance of faba bean plants towards the infection by $B$. fabae by inducing the accumulation of total phenols, total nitrogen, total protein and nucleic acids in yielded seeds as shown in Table 6.

\section{Discussion}

The present results revealed that the growth of shoot and root of faba bean plants were markedly inhibited by B. fabae infection. The reduction in fresh weight of infected faba bean shoots may be due to the toxins produced by the pathogen, which affected $\mathrm{K}$ uptake and

\begin{tabular}{|c|c|c|c|c|c|c|c|c|}
\hline \multirow{2}{*}{ Parameters } & \multirow[b]{2}{*}{$\begin{array}{l}\text { No. of pods I } \\
\text { plant }\end{array}$} & \multirow[b]{2}{*}{$\begin{array}{l}\text { No. of Seeds } \\
\text { /pod }\end{array}$} & \multicolumn{2}{|c|}{ Seed biomass (g) } & \multicolumn{2}{|c|}{ Pod biomass (g) } & \multirow[b]{2}{*}{$\begin{array}{c}100 \\
\text { seeds wt } \\
\text { (g) }\end{array}$} & \multirow[b]{2}{*}{$\begin{array}{c}\text { Seed yield /plant } \\
\text { (g) }\end{array}$} \\
\hline & & & Fresh & Dry & Fresh & Dry & & \\
\hline Cont & $8.7 \pm 0.141$ & $2.75 \pm 0.176$ & $0.821 \pm 0.020$ & $0.749 \pm 0.015$ & $3.09 \pm 0.108$ & $2.83 \pm 0.141$ & $87.29 \pm 0.519$ & $20.14 \pm 0.246$ \\
\hline $\mathbf{P}$ & $5.2 \pm 0.105$ & $1.62 \pm 0.141$ & $0.603 \pm 0.014$ & $0.534 \pm 0.017$ & $1.82 \pm 0.075$ & $1.44 \pm 0.105$ & $67.07 \pm 0.038$ & $6.46 \pm 0.225$ \\
\hline $\mathbf{F}$ & $7.2 \pm 0.263$ & $2.5 \pm 0.108$ & $0.780 \pm 0.015$ & $0.714 \pm 0.016$ & $2.91 \pm 0.107$ & $2.76 \pm 0.263$ & $85.31 \pm 0.022$ & $14.07 \pm 0.391$ \\
\hline$F+P$ & $6.4 \pm 0.281$ & $2.12 \pm 0.075$ & $0.714 \pm 0.019$ & $0.667 \pm 0.030$ & $2.43 \pm 0.127$ & $2.17 \pm 0.281$ & $80.66 \pm 0.199$ & $9.61 \pm 0.189$ \\
\hline SH & $8.6 \pm 0.172$ & $3.75 \pm 0.127$ & $0.894 \pm 0.013$ & $0.812 \pm 0.023$ & $4.12 \pm 0.113$ & $3.66 \pm 0.172$ & $92.44 \pm 0.203$ & $27.75 \pm 0.283$ \\
\hline $\mathrm{SH}+\mathrm{P}$ & $8.2 \pm 0.172$ & $2.75 \pm 0.113$ & $0.815 \pm 0.012$ & $0.754 \pm 0.014$ & $3.44 \pm 0.114$ & $3.17 \pm 0.172$ & $90.59 \pm 0.002$ & $20.15 \pm 0.172$ \\
\hline SA & $9.4 \pm 0.100$ & $4.25 \pm 0.113$ & $0.928 \pm 0.022$ & $0.833 \pm 0.023$ & $4.31 \pm 0.115$ & $3.72 \pm 0.172$ & $93.64 \pm 0.365$ & $34.06 \pm 0.471$ \\
\hline$S A+P$ & $9.2 \pm 0.172$ & $2.87 \pm 0.110$ & $0.845 \pm 0.010$ & $0.783 \pm 0.019$ & $3.61 \pm 0.110$ & $3.27 \pm 0.100$ & $91.25 \pm 0.183$ & $23.10 \pm 0.172$ \\
\hline $\mathrm{SH}+\mathrm{SA}$ & $8.8 \pm 0.141$ & $3.5 \pm 0.090$ & $0.912 \pm 0.012$ & $0.814 \pm 0.020$ & $4.17 \pm 0.101$ & $3.69 \pm 0.172$ & $92.05 \pm 0.268$ & $29.48 \pm 0.281$ \\
\hline $\mathrm{SH}+\mathrm{SA}+\mathrm{P}$ & $8.6 \pm 0.100$ & $2.75 \pm 0.126$ & $0.820 \pm 0.010$ & $0.772 \pm 0.015$ & $3.47 \pm 0.126$ & $3.21 \pm 0.100$ & $90.84 \pm 0.348$ & $18.26 \pm 0.283$ \\
\hline LSD at $P \leq 0.05$ & 0.30 & 0.62 & 0.090 & 0.065 & 0.47 & 0.34 & 0.92 & 1.38 \\
\hline
\end{tabular}

Table 3: Effect of shikimic acid, salicylic acid and their combination on yield and yield components of faba bean plants infected with chocolate spot disease. Data are represented as means \pm standard errors from 10 replicates.

\begin{tabular}{|c|c|c|c|c|c|c|}
\hline Parameters & $\begin{array}{l}\text { Straw yield } \\
\text { /plant } \\
\text { (g) }\end{array}$ & $\begin{array}{c}\text { Harvest } \\
\text { index }\end{array}$ & Crop index & $\begin{array}{c}\text { Relative seed yield } \\
(\%)\end{array}$ & $\begin{array}{c}\text { Biological yield } \\
\text { (g) }\end{array}$ & Mobilization index \\
\hline Cont & $21.94 \pm 0.077$ & $0.918 \pm 0.048$ & $0.478 \pm 0.009$ & $100.00 \pm 0.001$ & $42.08 \pm 0.009$ & $1.91 \pm 0.036$ \\
\hline $\mathbf{P}$ & $9.48 \pm 0.095$ & $0.682 \pm 0.051$ & $0.405 \pm 0.006$ & $32.10 \pm 0.379$ & $15.95 \pm 0.006$ & $1.68 \pm 0.051$ \\
\hline $\mathbf{F}$ & $15.43 \pm 0.079$ & $0.912 \pm 0.128$ & $0.476 \pm 0.008$ & $69.87 \pm 0.806$ & $29.52 \pm 0.006$ & $1.91 \pm 0.093$ \\
\hline$F+P$ & $12.38 \pm 0.062$ & $0.778 \pm 0.055$ & $0.437 \pm 0.012$ & $47.67 \pm 0.590$ & $21.99 \pm 0.015$ & $1.77 \pm 0.045$ \\
\hline SH & $29.10 \pm 0.111$ & $0.954 \pm 0.013$ & $0.487 \pm 0.011$ & $137.75 \pm 0.542$ & $56.81 \pm 0.008$ & $1.95 \pm 0.067$ \\
\hline $\mathrm{SH}+\mathrm{P}$ & $22.03 \pm 0.075$ & $0.911 \pm 0.042$ & $0.477 \pm 0.010$ & $100.03 \pm 0.448$ & $42.18 \pm 0.012$ & $1.91 \pm 0.042$ \\
\hline SA & $29.88 \pm 0.319$ & $1.140 \pm 0.068$ & $0.532 \pm 0.112$ & $169.06 \pm 1.275$ & $63.94 \pm 0.011$ & $2.14 \pm 0.068$ \\
\hline$S A+P$ & $21.04 \pm 0.062$ & $1.100 \pm 0.054$ & $0.524 \pm 0.149$ & $114.67 \pm 1.896$ & $44.14 \pm 0.010$ & $2.10 \pm 0.054$ \\
\hline $\mathrm{SH}+\mathrm{SA}$ & $29.51 \pm 0.107$ & $0.999 \pm 0.046$ & $0.499 \pm 0.080$ & $146.33 \pm 0.467$ & $59.00 \pm 0.112$ & $1.99 \pm 0.033$ \\
\hline $\mathrm{SH}+\mathrm{SA}+\mathrm{P}$ & $18.74 \pm 0.095$ & $0.981 \pm 0.057$ & $0.494 \pm 0.079$ & $90.62 \pm 0.646$ & $37.01 \pm 0.149$ & $1.98 \pm 0.070$ \\
\hline LSD at $P \leq 0.05$ & 1.03 & 0.07 & 0.02 & 0.06 & 1.82 & 0.07 \\
\hline
\end{tabular}

Table 4: Effect of shikimic acid, salicylic acid and their combination on yield and yield components of faba bean plants infected with chocolate spot disease. Data are represented as means \pm standard errors from 10 replicates. 


\begin{tabular}{|c|c|c|c|c|c|}
\hline \multirow{2}{*}{ Parameters } & \multicolumn{5}{|c|}{$\begin{array}{l}\text { Carbohydrates content } \\
\qquad\left(\mathrm{mg} \mathrm{g}^{-1} \mathrm{~d} w \mathrm{wt}\right)\end{array}$} \\
\hline & Glucose & Sucrose & TSS & Polysacchari-des & Total carbohydrates \\
\hline Cont & $0.015 \pm 0.000$ & $17.27 \pm 0.430$ & $44.48 \pm 0.354$ & $371.36 \pm 2.687$ & $415.85 \pm 3.041$ \\
\hline $\mathbf{P}$ & $0.004 \pm 0.000$ & $7.52 \pm 0.014$ & $35.52 \pm 0.141$ & $295.34 \pm 0.566$ & $330.87 \pm 2.910$ \\
\hline $\mathbf{F}$ & $0.013 \pm 0.001$ & $15.54 \pm 0.354$ & $43.97 \pm 0.349$ & $367.18 \pm 0.141$ & $411.16 \pm 0.495$ \\
\hline$F+P$ & $0.009 \pm 0.001$ & $11.70 \pm 0.041$ & $40.18 \pm 0.354$ & $342.12 \pm 0.566$ & $382.29 \pm 0.919$ \\
\hline SH & $0.022 \pm 0.001$ & $20.19 \pm 0.113$ & $48.78 \pm 0.041$ & $402.06 \pm 0.354$ & $450.85 \pm 0.424$ \\
\hline $\mathrm{SH}+\mathrm{P}$ & $0.017 \pm 0.001$ & $17.47 \pm 0.240$ & $44.81 \pm 0.354$ & $373.12 \pm 2.687$ & $417.94 \pm 1.301$ \\
\hline SA & $0.028 \pm 0.001$ & $22.32 \pm 0.240$ & $51.62 \pm 0.936$ & $514.67 \pm 0.566$ & $566.30 \pm 1.627$ \\
\hline$S A+P$ & $0.018 \pm 0.000$ & $19.59 \pm 0.071$ & $47.17 \pm 0.354$ & $420.15 \pm 0.141$ & $467.32 \pm 1.407$ \\
\hline SH+SA & $0.016 \pm 0.000$ & $21.00 \pm 0.354$ & $44.96 \pm 0.707$ & $383.20 \pm 1.105$ & $428.16 \pm 0.495$ \\
\hline $\mathrm{SH}+\mathrm{SA}+\mathrm{P}$ & $0.014 \pm 0.000$ & $19.04 \pm 0.318$ & $44.05 \pm 0.071$ & $375.71 \pm 1.980$ & $419.76 \pm 0.919$ \\
\hline LSD at $P \leq 0.05$ & 0.004 & 1.27 & 1.76 & 7.51 & 7.66 \\
\hline
\end{tabular}

Table 5: Effect of shikimic acid, salicylic acid and their combination on carbohydrates content ( $\mathrm{mg} \mathrm{g}^{-1} \mathrm{~d}$ wt) in yielded seeds of faba bean plants infected with chocolate spot disease. Data are represented as means \pm standard errors from 10 replicates.

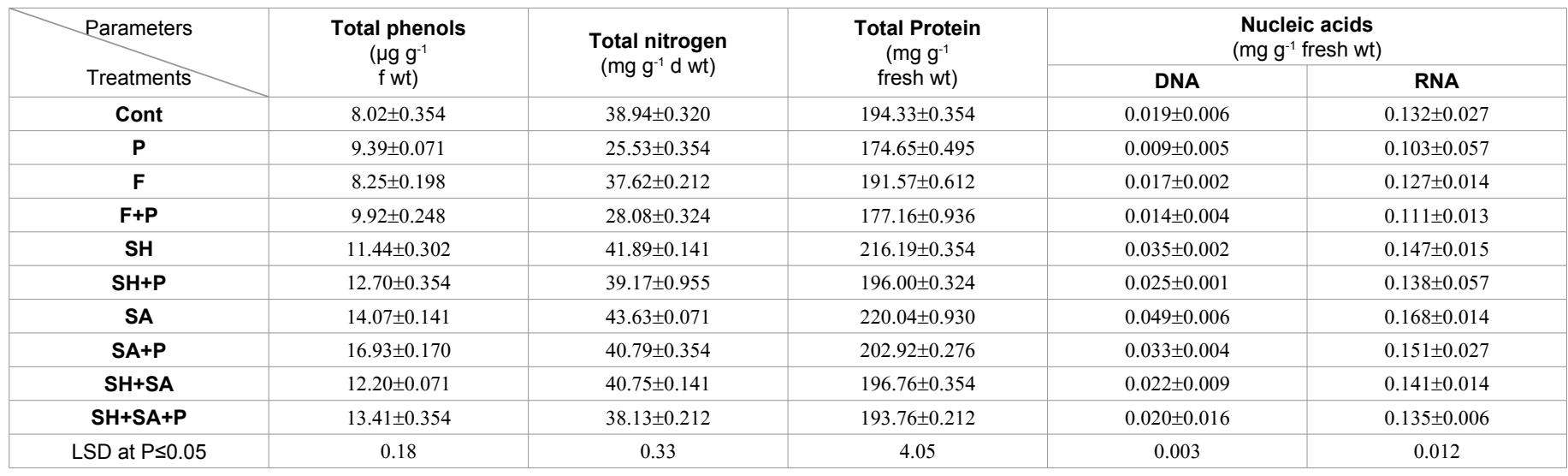

Table 6: Effect of shikimic acid, salicylic acid and their combination on total phenols ( $\mu \mathrm{g} \mathrm{g}^{-1} \mathrm{fwt}$ ), total nitrogen (mg g ${ }^{-1} \mathrm{~d}$ wt), total protein and nucleic acids (DNA \& RNA) contents ( $\mathrm{mg} \mathrm{g}^{-1}$ fresh wt) in yielded seeds of faba bean plants infected with chocolate spot disease. Data are represented as means \pm standard errors from 10 replicates.

stomata function leading to uncontrolled transpiration and excessive loss of water from plants as reported by Aducci et al. [23]. Meanwhile, the reduction in shoot dry weight might be related to increased rate of respiration and decompartementalization due to membrane degradation as suggested by Orcutt and Nilsen [24]. Furthermore, the present results showed that infection by $B$. fabae markedly decreased fresh and dry weights in roots of faba bean plants, and this may be related to the accumulation and action of phenolics produced from degradation of cell wall (lignin) mainly via depolymerization resulting from fungal elicitors [25].

The previous observations are in accordance with Hammad et al. [26] who investigated the effect of $B$. fabae on the growth parameters of faba bean and mentioned that the pathogen caused reduction in plant growth and the mean values of growth parameters in case of the resistant variety were higher than those of the susceptible one.

Application of phenolic compound greatly enhanced the growth vigor of both root and shoot of faba bean plants even under infection conditions. These results are in good conformity with the early finding of Hassan et al. [27] when they treated faba bean plants infected with chocolate spot disease with different phenolic elicitors and found that these treatments led to increase in fresh and dry weight of both shoot and root. Moreover, the tested chemicals are known to be medically safe for humans and animals. Furthermore, Panchera et al. [28] reported similar results on barley seedlings, where growth had been improved when the grains were pretreated with salicylic acid.
Treatment of tomato plants with salicylic acid led to the increase of fresh and dry weights of these plants under infection by Alternaia solani [29]. In this respect, Huang et al. [30] reported that salicylic acid is now considered to be a hormonal substance that plays a key role in regulating plant growth and development.

Abd El-Hai et al. [31] found that seed presoaking in combination of salicylic acid with citric acid caused significant increase in plant height, number of leaves per plant and plant yield in sunflower plant infected with Rhizoctonia solani and Macrophomina phasoliana. Galal et al. [32] reported that treatment of tomato plant with salicylic acid alone or in combination with citric acid recorded the highest value traits of tomato plants.

Stem diameter and height of the plants are increased by $10^{-10}$ and $10^{-8} \mathrm{M}$ salicylic acid. Similarly, applications of $10^{-8}$ and $10^{-6} \mathrm{M}$ salicylic acid increased fresh stem weight, dry stem weight and root length [33].

The increase in leaf area production caused by shikimic acid application could be resulted from the rapid rate of nutrients movement and hormones transport through transpiration stream from root, which can accelerate the rate of leaf expansion in the developing leaves. Shikimic acid caused also a marked increase in root length of faba bean plants, leading to increase in the rate of water uptake from the soil and this effect explain the significant increase in fresh weight of root and shoot of infected faba bean plants. These results are in accordance with that of Aldesuquy and Ibrahim [6] who reported that treatment 
of Vigna sinensis with shikimic acid caused an increase in its growth parameters.

Yield and yield attributes are significantly reduced in response to infection. The reduction in yield of infected faba bean plants can be attributed to the decrease in photosynthetic pigments. A decline in leaf quantity and leaf area may reduce flower bud formation and yield potential. The decrease in yield and yield components in different crops under similar conditions has also been reported by many workers [27,34]. Furthermore, the aforementioned pattern of results were in harmony with those of Mahmoud et al [35] who mentioned that faba bean plants lost about $40 \%$ of its productivity due to $B$. fabae infection.

The application of shikimic acid, salicylic acid or their combination induced significant effect in alleviating the adverse effects of infection on yield and yield components of faba bean plants. This increase could be attributed to the antagonistic effect of shikimic acid or salicylic acid on $B$. fabae as discussed previously or may be attributed to the increase in plant growth rate. These results are in conformity with those obtained by Aldesuquy and Ibrahim [6] who reported that seed presoaking with shikimic acid improves the growth parameters of cowpea plants by increasing the turgidity, stimulating leaves expansion, enhancing the production of photosynthetic pigments [11] as well as the massive increase in photosynthetic activity. Furthermore, shikimic acid increases the yield capacity by inducing a massive increase in the pod length, numbers of pod/plant, numbers of seeds/pod and seed biomass as well as increases the protein, total soluble sugars and sucrose contents.

The beneficial effect of salicylic acid on seed yield may be due to translocation of more photoassimilates to seeds during seed formation and it has the capacity to both directly or indirectly regulate yield. In this respect, $[31,36]$ reported that salicylic acid showed an effective role in ameliorating the effects of infection on plant yield.

Data revealed that there is a significant reduction in the carbohydrates, total nitrogen, and nucleic acid contents (DNA \& RNA) in faba bean seeds as a result of pathogen infection. On contrary, the infection induced dramatic increase in phenols content in yielded faba bean seeds.

The noticeable reduction in carbohydrate content in yielded faba bean seeds of infected plants may probably be due to firstly, the pathogen may induce increase in hydrolytic enzymes which degrade carbohydrates and secondly, pathogen may consume the reducing sugars resulted from degradation of carbohydrates as a respiratory substrate to evolute energy [37].

The significant decrease in the total protein content may be due to some activities related to a hypersensitive response [38]. In this respect, Mahmoud, et al. [35] reported that the variation in protein content was ascribed to the effect on the cytoplasmic ribosomes, the synthesis of RNA by plant cells, which in turn play an important role in protein biosynthesis, and/or nitrate reductase activity in plant leaves. In addition, Narayanasamy [39] reviewed that proteins were hydrolyzed through polypeptides to small peptides and further broken down to amino acids by increasing activity of protease enzymes, which raise the soluble nitrogen content in the fungal infected seeds. Consequently, the protein degradation was accelerated by hydrolysis to meet the requirements of pathogen development.

Gozzo [40] mentioned that, the central role of salicylic acid as a signal transducer of SAR was demonstrated in transgenic plants where it could not be detected. Furthermore, Obradovic and Jones [41] revealed that plants responded to a local infection treated with salicylic acid had led to systemic expression of broad spectrum and long-lasting disease resistance that is efficient against fungi, bacteria and viruses.

Salicylic acid was more effective in increasing of total proteins in infected faba bean plants. This finding is supported by the results of Ali et al. [42] who reported that close correlation between the levels of total soluble proteins in response to salicylic acid pointed to exert their action mechanism upon DNA- RNA synthesizing protein machinery at transcriptional and/or translational levels with magnitudes.

The deleterious effect on nucleic acid (DNA \& RNA) content due to infection may be attributed to the reduction in total carbohydrates and total nitrogen contents or increased RNase activity. This suggestion was strongly supported by several investigators $[43,44]$ who reported that RNase gene expression and activity often increase in response to pathogen attack. Moreover, Booker [45] reported that Ribonucleases (RNases) degrade RNA and exert a major influence on gene expression during development and in response to biotic and abiotic stresses.

Reduction in DNA content in yielded seeds infected by B. fabae might be due to the breakdown or denaturation of nucleotides, the substructures of DNA (deoxyribose sugar molecules, nitrogenous bases and phosphate groups). On the other hand, the increase in DNA and RNA in faba bean seeds in response to shikimic acid, salicylic acid or their combination could be attributed to the enhancement of nucleic acid biosynthesis and/or inhibition of their degradation.

\section{Conclusion}

It can be concluded from this study that chocolate spot disease had negative effects on growth, and productivity of faba bean plants. In addition, the fungicide used throughout this study (Ridomil MZ) might represent a stress signal in the uninfected plants and gave only partial control of chocolate spot disease to infected plants. On the other hand, seed presoaking in phenolic compounds such as shikimic acid, salicylic acid or their combination displayed a positive role in increasing the resistance of infected faba bean plant towards $B$. fabae infection by alleviating the stress induced by the pathogen on plant growth vigor and internal ultrastructure of mesophyll cells [11] of faba bean plants. Therefore, the prospect for the future is good for the application of phenolic compounds because of the lessened availability of fungicides to protect crop plants. Moreover, we recommended the application of such phenolic compounds separately because of the insignificance effect of their combination which may be attributed to its overdose on the plant. In addition, the most effective treatment in enhancement faba bean was salicylic acid.

\section{References}

1. Torres AM, Roman B, Avila CM, Satovic Z, Rubiales D, et al. (2004) Faba bean breeding for resistance against biotic stresses: towards application of marker technology. Euphytica 147: 67-80

2. Elwakil MA, El-Refai IM, Awadallah OA, El-Metwally MA, Mohammed MS (2009) Seed-borne pathogen of faba bean in Egypt: detection and pathogenicity. Plant Pathol J 8: 90-97.

3. Reglinski T, Whitaker G, Cooney JM, Taylor JT, Pooles PR, et al. (2001) Systemic acquired resistance to Sclerotinia sclerotiorum in kiwi fruit vines. Physiol Mol Plant Pathol 58: 111-118.

4. El-Hendawy S, Shaban W, Sakagami JI (2010) Does treating faba bean seeds with chemical inducers simultaneously increase chocolate spot disease resistance and yield under field conditions? Turk J Agric For 34: 475-485.

5. Hatfield RD, Ralph J, Grabber JH (1999) Cell wall cross-linking by ferulate in grasses. J Sci Food Agric 79: 403-407.

6. Aldesuquy HS, Ibrahim A (2000) The role of shikimic acid in regulation of 
Citation: Soliman AH (2015) Shikimic Acid and Salicylic Acid Induced Protection on Growth Vigor, Seed Yield and Biochemical Aspects of Yielded Seeds of Vicia faba Plants Infected by Botrytis fabae. J Plant Pathol Microb 6: 304. doi:10.4172/2157-7471.1000304

growth, transpiration, pigmentation, photosynthetic activity and productivity of Vigna sinensis plants. Phyton 40: 277-292.

7. Wu HS, Raza W, Fan JQ, Sun YG, Bao W, et al. (2008) Antibiotic effect of exogenously applied salicylic acid on in vitro soilborne pathogen, Fusarium oxysporum f.sp.niveum. Chemosphere 74: 45-50.

8. Hayat Q, Hayat S, Irfan M, Ahmad A (2010) Effect of exogenous salicylic acid under changing environment: A review. Environ Ex Bot 68: 14-25.

9. El-khodary SFA (2004) Effect of salicylic acid on the growth, photosynthesis and carbohydrate metabolism in salt stressed maize plants. Int J Agric Biol 6 : $5-8$

10. Larque-Saavedra A, Martin-Mex F (2007) Effects of salicylic acid on the bioproductivity of the plants. In: Hayat S and Ahmad A. (Eds.): Salicylic Acid: A Plant Hormone. Springer Publishers, Dordrecht, Netherlands.

11. Baka ZAM, Aldesuquy HS, Abbas MA, Alazab NT (2012) Effect of shikimic and salicylic acids on the ultrastructure of chloroplasts of Vicia faba infected by Botrytis fabae. J Environ Sci 41: 37-54.

12. Arduini I, Godbold DG, Onnis A (1994) Cadmium and copper change roo growth and morphology of Pinus pinea and Pinus pinaster seedlings. Physio Plant 92: 675- 680.

13. Beadle CL (1993) Growth analysis. In: Hall, D.C., Scurlock, JMO, Bolhar HR., Leegod, RC and Long S.P. (Eds.): Photosynthesis and Production in a Changing Environment. A field and laboratory manual. Chapman and Hall, London. pp: 36- 46.

14. Feteris WA (1965) A serum glucose method without protein precipitation. Am $J$ Med Technol 31: 17-21.

15. Van Handel E (1968) Direct microdetermination of sucrose. Anal Biochem 22 280-283.

16. Yemm EW, Willis AJ (1954) The estimation of carbohydrates in plant extracts by anthrone. Biochem J 57: 508-514.

17. Thayermanavan V, Sadasivam S (1984) Determination of total carbohydrates by anthrone method. Plant Foods Hum Nutr 34: 253-257.

18. Chibnall AC, Rees MW, Williams EF (1943) The total nitrogen content of egg albumin and other proteins. Biochem J 37: 354-359.

19. Sadasivam S, Manickam A (1996) Biochemical Methods. 2nd ed. New Age Inter. Limit. Publ. New Delhi, India.

20. Bradford MM (1976) A rapid and sensitive method for the quantitation of microgram quantities of protein utilizing the principle of protein-dye binding. Anal Biochem 72: 248-254

21. Malik CP, Singh MB (1980) Estimation of Total Phenols in Plant Enzymology and Histo-enzymology. Kalyani Publishers, New Delhi.

22. Snedecor GW, Cochran WG (1976) Statistical Methods. 6th ed. Oxoford IBH Publishing Co. New Delhi.

23. Aducci P, Ballio A, Marra M (1997) Phytotoxins as molecular signals. In: Aducci, P. (Ed.): Signal Transduction in Plants. Birkhauser Verlag, Basel, pp: 83-105.

24. Orcutt DM, Nilsen ET (2000) Influence of plant phytopathogens on host physiology. In: Orctt, D.M. and Nilsen, E.T. (Eds.): The Physiology of Plants under Stress. Soil and Biotic Factors, John Wiley \& Sons, Inc. USA, pp: 239263.

25. Steijl H, Niemanm GJ, Boon JJ (1999) Changes in chemical composition related to fungal infection and induced resistance in carnation and radish investigated by pyrolysis mass spectrometry. Physiol Mol Plant Pathol 55: 297-311.

26. Hammad IA, Migahed FF, Nofel AMM (2001) Effect of B. fabae and lithium chloride on mitotic cell division and morphology of Vicia faba. Afr $\mathrm{J}$ Mycol Biotechnol 9: 45-61.
27. Hassan MEM, Abd El-Rahman SS, El-Abbasi IH, Mikhail MS (2007) Changes in peroxidase activity due to resistance induced against faba bean chocolate spot disease. Egypt J Phytopathol 35: 35-48.

28. Panchera TV, Popova LP, Uzunova AN (1996) Effect of salicylic acid on growth and photosynthesis in barley plants. J Plant Physiol 149: 57-63.

29. Faheed FA, Abd-Elaah GA, Mazen A (2005) Alleviation of disease effect on tomato plants by heat shock and salicylic acid infected with Alternaria solani. Int J Agric Biol 7: 783-789.

30. Huang RH, Liu JH, Lu YM, Xia RX (2008) Effect of salicylic acid on the antioxidant system in the pulp of 'Cara cara' navel orange (Citrus sinensis (L.) Osbeck) at different storage temperatures. Posthar Biol Tech 47: 168-175.

31. Abd El-Hai KM, El-Metwally MA, El-Baz SM, Zeid AM (2009) The use of antioxidants and microelements for controlling damping-off caused by Rhizoctonia solani and charcoal rot caused by Macrophomina phasoliana on sun flower. Plant Pathol J 8: 79-89.

32. Galal AA, Hoda AM, Fawzi ZF 2005 Improving of tomato growth, health earliness, productivity and fruit quality by chemically induced systemic resistance. J Appl Sci Res 5: 362-372.

33. San-Miguel R, Gutiérrez MO, Larqué-Saavedra A (2003) Salicylic acid increases the biomass accumulation of Pinus patula. South J Appl For 27: 5254.

34. Rashad YM, Abdel-Fattah GM, Shabana YM, Lashin Al (2005) The use of some control measures for the management of the brown spot disease of rice. M.Sc. Thesis, Bot. Dept., Fac of Sci, Mansoura Univ, Egypt.

35. Mahmoud YAG, Ebrahim MKH, Aly MM (2004) Influence of some plant extracts and microbiaogents on some physiological traits of faba bean infected with Botrytis fabae. Turk J Bot 28 519-528.

36. Hadi MR, Balali GR (2010) The effect of salicylic acid on the reduction of Rhizoctonia solani damage in the tubers of marfona potato cultivar. Am-Euras J Agric Environ Sci 7: 492-496.

37. Baka ZAM, Aldesuquy HS (1992) Studies on powdery mildew fungus Spherotheca fuliginea: Ultrastructure and host responses. Acta Bot Hung 37 15-31.

38. Chandra A, Bhatt RK (1998) Biochemical and physiological response to salicylic acid in relation to the systemic acquired resistance. Photosynth 35: 255-258.

39. Narayanasamy P (2006) Postharvest Pathogens and Disease Management. John Wiley \& Sons, Inc Hoboken, pp: 578

40. Gozzo F (2004) Systemic acquired resistance in crop protection. Outlooks on Pest Manag 15: 20-23.

41. Obradovic A, Jones JB (2005) Integration of biological control agents and systemic acquired resistance inducers against bacterial spot in tomato. Plant Dis 89: 712-716

42. Ali MB, Hahn EJ, Paek KY (2007) Methyl jasmonate and salicylic acid induced oxidative stress and accumulation of phenolics in Panax ginseng bioreactor root suspension cultures. Molecules 12: 607-621.

43. Lusso M, Kuc J (1995) Increased activities of ribonuclease and protease after challenge in tobacco plants with induced systemic resistance. Physiol Mol Plant Pathol 47: 419-428.

44. Galiana E, Bonnet P, Conrod S, Keller H, Panabie'res F, et al. (1997) RNase activity prevents the growth of a fungal pathogen in tobacco leaves and increases upon induction of systemic acquired resistance with elicitin. Plant Physiol 115: 1557-1567.

45. Booker FL (2004) Influence of ozone on ribonuclease activity in wheat (Triticum aestivum) leaves. Physiol Plant 120: 249-255. 